УДК 81+811.111'01

ББК 81.2Англ-03

DOI: https://doi.org/10.17308/lic.2020.2/2842

\title{
ЭВОЛЮЦИЯ ПРЕДСТАВЛЕНИЙ О ЖИЛИЩЕ И ЕГО НОМИНАЦИЙ В ДРЕВНЕ- И СРЕДНЕАНГЛИЙСКИЙ ПЕРИОДЫ
}

\author{
Ю. С. Растворова, Е. А. Пушкарев \\ Высшая икола экономики
}

\section{THE EVOLUTION OF THE CONCEPT OF A LIVING SPACE AND ITS NOMINATIONS IN THE OLD AND MIDDLE ENGLISH PERIODS}

\author{
Yu. S. Rastvorova, E. A. Pushkarev \\ Higher School of Economics
}

\begin{abstract}
Аннотация: статья посвящена вопросу о развитии и изменении представлений носителей английского языка о жилище в пределах др.-a.-c.-a. периодов. Авторы моделируют конщепт жилище двух периодов через анализ его языковых репрезентаиий. В фокусе внимания - причины появления новых когнитивных признаков исследуемой категории и исчезновения старых в сознании средневекового британца. Диахронический анализ лексики, манифестирующей изучаемый конщепт, осуществляется в рамках интерпретациинных полей, что предположительно дает возможность проследить эволюцию категоризации действительности средневековым сознанием в области жилища на примере двух временных отрезков (VII-XI вв. и XI-XIV вв.). Для большей объективности авторы опираются не только на языковые средства, репрезентирующие категорию жилище, но и на доступные артефакты: архитектурные памятники Британии VII-XIV вв. и другие материальные свидетельства устройства быта эпохи. Выявляются характерные черты жилища др.-а. и с.-а. периодов и реконструируются представления англоязычного кониептоносителя в этой области.

Ключевые слова: диахрония, эволющия концепта жилище, древнеанглийский период, среднеанглийский период, категоризация действительности, структура концепта, артефактьл.
\end{abstract}

\begin{abstract}
: the article addresses the question of how the image of a living space evolved and changed between the Old and Middle English periods in the mind of an English speaker, as well as the nominations they used to name artifacts associated with dwellings. Such images are modelled by means of mapping the concept $\mathbf{d w e l l i n g}$ as it was in $O E$ and ME via its physical manifestations - words. The authors focus on the reasons why new cognitive features of this category may have appeared, while other characteristics of the concept became obsolete in the mind of the medieval Brit. The diachronic analysis of the lexis in correlation with this concept is based on the theory of interpretation fields, which is arguably the best method to trace the many changes in the way dwellings were pictured in the Middle Ages. The authors back their opinion with the analysis of various artifacts associated with dwellings and their functions: medieval buildings, architectural photography, book descriptions of houses, etc. The core features of medieval dwelling are defined as they may have been perceived by native English speakers centuries ago.

Key words: diachronic studies, the concept of a living space, the OE and ME period, cognitive categorization, concept structure, artifacts.
\end{abstract}

\section{Введение}

Данная статья является интегральной частью широкого исследования, посвященного моделированию концептуального представления о жилище у британцев, и рассматривает диахронические преобразования, которые имели место как в структуре концепта, так и в номинациях, коррелирующих с ним.

(C) Растворова Ю. С., Пушкарев Е. А., 2020 
Несмотря на большое число работ по когнитивной проблематике, до настоящего времени не существует единого подхода и универсальной методики изучения концептов. Соответственно, нет и всестороннего анализа концепта жилище (в том числе и в английском языковом сознании). Лингвисты опираются на языковые репрезентации концепта, зачастую игнорируя такие объекты материальной культуры, как археологические артефакты, предметы живописи, фотографии и т. п. [1, с. 130; 2; 3]. В то же время ряд исследователей отмечают, что историки и культурологи рассматривают жилье как компонент социальной, политической и экономической жизни общества, часто не уделяя должного внимания его структуре и функции, а также представлениям индивида о жилище в данный исторический период [4-6]. Изучение лексики, обозначающей жилища или принадлежащей к сфере жилья, проводились в рамках сравнительно-исторического, типологического и сопоставительного языкознания на материале русского, немецкого и английского языков [7-11]. В данных трудах исследуются лексика семантических полей, ассоциируемых с жилищем, различные синонимические отношения внутри лексико-семантических и тематических групп «жилые здания и помещения», «жилая комната», «архитектурные конструкции», а также проводится сопоставительный анализ отдельных характеристик лексики, служащей для обозначения реалий дома.

Актуальность данного исследования обусловлена не только разработкой когнитивно-лингвистической проблематики соотношения языка и мышления, с одной стороны, и осмысления роли человека в языке с другой, но и обращением к более узкой области эволюционных изменений диахронического спектра в модели концепта. Изучение типов жилищ и средств их языковой репрезентации позволяет получить представление как о структуре идиосинкратического концепта жилище средневекого индивида, так и о концептуальном представлении о жилье на уровне языкового социума. Также необходимо отметить универсальный характер исследуемого концепта и его значимость для представителей разных культур.

Интерес вызывает вопрос о том, насколько изменились представления о жилье в динамике и как эволюционировала структура данного концепта в течение двух периодов. Для решения этой задачи наиболее целесообразным является комплексное исследование, включающее в себя как изучение языковых средств - номинаций жилища, так и доступных артефактов, связанных с жилищем (археологических находок, сохранившихся изображений дома, архитектурных фотографий и т. п.). Материалом исследования послужили лексикографические источники, среди которых основными являются наиболее совре- менный и авторитетный корпусный справочник Тhe Middle English Compendium of the University of Michigan [12], англосаксонский словарь Дж. Босворта и Т. Толлера [13], другие этимологические словари, а также архитектурные словари и справочники. В качестве методов исследования использовались концептуальный, компонентный и инферентный анализы, а также частично архитектурный анализ. Такой подход обеспечивает научную новизну и теоретическую значимость исследования концепта жилище в синхронии и диахронии.

\section{Терминология и определения}

Под концептом в данной работе понимается базовая мыслительная единица, которая отражает и интерпретирует явления действительности, «пучок представлений», сопровождающий слово, который обладает относительно упорядоченной внутренней структурой и является результатом когнитивной деятельности личности [14-16]. Структура концепта определяется структурой отражаемого индивидом мира $[17$, с. 266], при этом, признавая отсутствие четкого изоморфизма между структурой концепта и структурой языковой формы, следует согласиться с наличием корреляции между ними. Это, в свою очередь, позволяет реконструировать план содержания (т. е. концептуальное представление о жилище) через анализ плана выражения - десигнаторов (т. е. номинаций жилища), а для верификации подобных корреляций - прибегнуть к анализу явлений неязыкового, вещного мира. Таким образом, методологически в данном исследовании используются два подхода к изучению материала: от номинаций к концепту жилища и обратно.

Ядро концепта - это минимальный набор когнитивных признаков, определяющий основные отличительные черты концептуализированного предмета или понятия [18], а его интерпретационное поле содержит в себе когнитивные признаки, дополняющие содержание концепта. Модель концепта жилище гипотетически отражена в структуре номинативного поля, состоящего из лексических единиц, характеризующих данный участок действительности $[19$, с. 9]. Критерием отбора лексических единиц послужили те когнитивные признаки концепта, которые представляют его информационное содержание, или ядро. Как правило, ими оказывалось номинативно-непроизводное значение слов house, hom, dwellinge, которое можно определить как 'здание / конструкция для проживания людей/животных’. Bce лексические единицы, в семантике которых выявлены эти признаки, признаются репрезентантами концепта жилище. 
Диахронические изменения концепта жилище в древне- и среднеанглийский периоды и его языковые репрезентации

Диахронический анализ номинаций предполагает описание состояния и характера обозначений по периодам, с последующим сравнением и сопоставлением данных и выявлением как общих, так и отличительных черт жилища в разные исторические периоды и обозначающих его слов.

Говоря о категоризации действительности сознанием, следует учитывать, что интерпретационное поле в определенной степени отражает то, как индивид категоризирует действительность. Структура любого поля предполагает ядро, содержащее обычно многозначное, нейтральное и, как следствие, наиболее частотное слово-репрезентант (или несколько слов-репрезентантов).

Для древнеанглийского поля когнитивных признаков жилища такими словами оказались несколько слов широкой семантики, которые были выявлены с помощью дефиниционно-компонентного анализа лексики, репрезентирующей данный концепт: wic, hús, heall, hám, tún, éðel, flet. Все эти слова нерасчлененно выражают понятие 'жилище', обозначают большое количество жилищ различных типов, являются полными или частичными синонимами. В среднеанглийский период ядро сокращается до трех конституентов (hous, hom и dwellinge), что объясняется широкозначной природой их д.-а. соответствий. Например, слово tún номинировало любое жилое пространство человека (a habitation of men in a general sense; a manor, villa, an estate... under a lord's jurisdiction), а также по метонимии прилегающие к дому территории, часто огороженные (an enclosed land surrounding a single dwelling; a yard, court, garden; a town) [13]. Еще одно широкозначное слово heall нерасчлененно обозначало большое жилище: дом (a residence), и образованные по метонимии часть дома - холл (a hall), отдельную комнату во дворце (a large room forming part of the residence of a great man), отдельный элемент дома (a corner, an angle), а также храм (a temple), суд (a court of law), которые часто находились на территории такой резиденции [13].

Остальные манифестанты ядра концепта также полностью или частично дублируют семантику друг друга, что явилось причиной исчезновения некоторых из них из словарного состава в среднеанглийский период. Так, в ср.-а. языке не зафиксированы лексемы éðel и wic, которые стали избыточными вследствие того, что являлись полными синонимами остальных конституентов ядра. Wic обозначало ‘особняк' наряду с tún и bold; сема 'жилье животных' повторялось у éðel и hus, 'совокупность домов, деревня, город' - у слова tún, а значение 'временное обиталище' дублировалось в словах периферии интерпретационного поля logging, logge, hoste. Древнеанглийское слово éðel все еще сохраняется в словаре среднеанглийского языка Г. Курата, но к тому времени оно уже утратило значение 'жилище' и приобрело новое значение 'страна, унаследованная от предков, родина' и, таким образом, было вытеснено из ядра новым словом $d$ wellinge, которое вошло в обиход только в XIV в. со значением 'жилище в общем смысле'. Однокоренной глагол dwellan зафиксирован в древнеанглийском языке, но со значением 'обмануть, ввести в заблуждение', значение же 'жить, населять' появилось только в ср.-а. период [13]. Слова toun, heal и flet заняли место на периферии поля в ср.-а., утратив когнитивный признак 'здание / конструкция для проживания человека/животного', поскольку его уже номинировали ham и hous. Toun сохранило значение 'город, населенный пункт', поскольку имевшееся у него значение 'помещичий дом, усадьба' было вытеснено французским словом maner; heal в ср.-а. период также утрачивает значение 'жилище' и развивает ряд более конкретных: 'большая частная резиденция', 'дворец', 'замок', возникшие на основе значений др.-а. слова heal; flet сохранило значение 'жилой дом', 'зал' и утратило значение 'коттедж', которое было вытеснено французским заимствованием cottage, выражавшим только данное понятие. Во второй половине ср.-а. периода заметна тенденция к сужению значения flet, которое стало употребляться преимущественно для обозначения жилища керла, рядового общинника [20]. В это же время у flet развилось значение 'комната или дом с мощеным полом', которое и закрепилось за этим словом в ср.-а. языке. Вероятно, это значение возникло с появлением новой реалии - мощеного пола в домах.

Ядерные слова ham и hous сохранили в своей семантике центральные когнитивные признаки, и, таким образом, заняли место в ядре среднеанглийского номинативного поля жилище. Они в значительной степени изменили свое лексическое содержание. Эти два слова занимают сильную, устойчивую позицию в языке, поскольку они многозначны, продуктивны - от них образовано множество сложных слов и устойчивых словосочетаний. Они охватывали весь спектр значений, связанный с представлениями о жилище. Являясь близкими синонимами и имея сходное развитие значений, они в др.-а. и ср.-а. периодах не конкурируют, а дополняют друг друга.

Так, в др.-а. языке оба слова обозначали дом, жилище, место, но hus было более емким в семантическом отношении словом и номинировало большее количество объектов - жилищ различного типа, различного назначения, например, здание для проживания людей (a building for human habitation), часть дома для жильца или семьи (a portion of a building occupied by one tenant or family), дом с очагом, печью, жаровней 
(a place of the fiery furnace), дом для гостей, гостиница (a building for the entertainment of travellers, a public house, an inn), храм (a place of worship, church, temple), монастырь (a place of abode of a religious fraternity), жилище животных (a building for keeping animals), временное жилище (a temporary erection, tabernacle) и др. [13]. В ср.-а. период у слова hom развиваются периферийные значения, тогда как основные, интенсиональные, сохраняются. Вместо одного значения в ср.-а. периоде hom развивает пять: дворец, сарай для свиней, поместье (дом с землей), место для отдыха, убежище. При этом семантика hous остается почти без изменений, но с развитием значения 'дворец' у hom hous теряет его. Далее оба слова имели синонимичные значения 'жилище животного', но в слове hom это более узкое значение: 'сарай для свиней', а в слове hous - более общее: 'постройка для проживания домашних животных и птиц’. У hom сохранилось значение 'дом с земельным участком, поместье', которого нет у hous. В свою очередь, значение 'место для временного проживания, дом для гостей' сохраняется в семантике hous, но не зафиксировано у ср.-а. hom.

В ср.-а. языке у hus так же, как и в словах hom, bold, flet, heal, сохраняются ядерные семы 'здание / структура для проживания’, но у слов toun, wic и éðel эти значения отмирают, очевидно, в силу того, что они имеются у более устойчивых слов, в связи с чем эти слова выходят из состава лексики, репрезентирующей концепт жилище.

Лексемы на периферии поля группируются на основании когнитивного признака, который является для них интегральным. Например, четко выделяется группа, которая объединяет лексику с когнитивным признаком жилище в общем смысле, куда входят как слова широкой семантики, так и лексемы с единственным значением 'жилище, обиталище': eardwic (а dwelling), eardunghus (a habitation), éðel-stów (a dwelling-place), hám (a home, house, residence, habitation), wic (a dwelling-place, abode, habitation, residence, lodging, quarters) и некоторые другие. В среднеанглийском группа с таким признаком сохраняется, однако меняется ее состав. Практически все лексические единицы, ее составляющие, выходят из употребления либо переходят в группы, объединенные другим когнитивным признаком. На их место приходят французские заимствования (и дериваты с французскими морфемами) habitacioun (a place of lodging, abode or settlement; a dwelling place or residence), residence (a dwelling place; also eccl. of a clergyman), dwelling-place и т. д. [12]. В группе с интегральным признаком 'большой, богатый': (kyninges) bold (King's house), boldwela (a dwelling of wealth or happiness), cyne-stol (a royal throne or dwelling), hám (an estate), hús (a palace), и т. д., в которой сохраняет- ся только hom, остальные лексемы либо были просто вытеснены французскими заимствованиями, либо происходило перераспределение их значений.

Например, понятие 'дом короля, дворец', которое в др.-а. период выражалось словом hus, в ср.-а. «перешло» к hom; значение 'дворец' в слове hus было вытеснено французским заимствованием palais, которое употреблялось тогда только для обозначения дворца и заняло прочную позицию в английском языке, образовав словосочетания kings palais, roial palais, palatic chaumbre и др. Кроме того, сочетания c palais вытеснили и другие лексемы, выражавшие соответствующие понятия в др.-а. период: boldvela, cynebold, resed, palense, cyning wic, seld, cyne-stol.

Отмирание подобных сложных слов можно объяснить тем, что, выражая понятие 'дворец', они имели, очевидно, меньше шансов на выживание, будучи производными и сложными по структуре, в то время как palais было простым, более специализированным, а значит, более продуктивным. Кроме того, ср.-а. период был эпохой господства французского языка, на котором разговаривала верхушка общества, что давало преимущество определенному слою французской лексики перед английской. Слова resed, palendise, seld, будучи простыми, уступали слову palais в продуктивности (от них образовано всего по одному производному слову). Resed также имело значения 'здание', ‘дом', ‘зал', с которыми конкурировали подобные же значения ядерных слов hous и heal. В результате слово resed, как занимающее более слабую позицию в языке по сравнению с ядерными словами, стало избыточным и вышло из употребления в ср.-а. период. То же самое произошло со словом seld, которое не выдержало конкуренции со стороны heal, palais, residence, занявших прочную позицию в системе языка. Они быстро ассимилировались, доказательством чему являются многочисленные сочетания с исконно английскими глаголами (maken residence, holden residence, kepen residence, etc.) и появившиеся однокоренные слова (resident, residen). Таким образом, лексические единицы, служившие номинацией дворцам разного типа в др.-а. языке, уступили место более жизнеспособному palais, вошедшему из французского в ср.-а. период.

Группа с признаком 'военный, укрепленный' также пополняется за счет французской лексики clos (a stronghold), cloister (a walled place such as a castel), logge (portable lodgements of an army on the march; a tent) [12]. Из позднего др.-а. в группу перешло только castel, остальные слова вышли из употребления либо потеряли признак 'военный' и перешли в состав других групп.

Группа 'съемное жилище' в др.-а. включала в себя cumena-hus (inn), gast-hof, gasthus (a guest-house, guest-chamber), hus (inn) inna (lodging). Значение 'дом 
для гостей' (inn) номинировали др.-а. слова giest-hus, gast-hof, spraechus и также hus, которое сохранило это значение в ср.-а. период. Тогда же (в ср.-а.) появляется и сосуществует с ними целый ряд заимствований, выражающих понятие 'гостиница': hostelrie, hostel, host, hostage. Эти слова являются однокоренными, что, вероятно, обеспечивает им определенную устойчивость в языке. Помимо них, от этого же корня образованы глаголы hosten, hostelen, причастие II hostelled и др. Этот факт говорит о том, что лексемы с корнем host уже практически ассимилировались в cp.-а. языке и прочно заняли свое место в его системе.

В группе, объединенной признаком 'монастырь, церковь' наблюдается почти полная смена словарного состава. Др.-а. слова mynsterclyse, mynsterham, mynsterlif и др. были вытеснены французской лексикой abbeie, abbodrice, abbathie, cloister, dormitorie, hospital, hostelrie, mansion, monasyterie, и т. п. Очевидно, сильное влияние на общество оказало распространение французского католичества, что отразилось в номинациях религиозных реалий. Сохранились исконно английские bold, cell, hous, которые номинировали дом человека и животного, часть дома и, в том числе жилище монашества.

Подобное положение наблюдается практически во всех группах, конституирующих интерпретационное поле концепта жилище: поменялся словарный состав за счет новых слов, но при этом почти все группы, а соответственно, и когнитивные признаки концепта жилище остались неизменными.

Интерес представляет группа лексем, объединенная признаком 'жилище животного'. В др.-а. языке для их номинации использовались широкозначные слова. Например, в семантике др.-а. éðel и hám объединены представления о единичном объекте (доме, обиталище животного), о нематериальном жилище (Бога, дьявола), о месте сосуществования членов социума (страна, родина) [21].

Значение 'дом животного' др.-а. слова hus сузилось в ср.-а. до более конкретного 'строение для содержания домашних животных и птиц’, и ср.-а. hous уже часто выступает в качестве компонента сложного слова: douves-hous, bullok-hus, cou-hus. Жилище же диких животных номинировали слова hole, leir, cave и др.

Кроме др.-а. широкозначных слов, зафиксированы лексемы, номинировавшие жилища диких животных: cofa (cave), eorthsele (hole), hola (hole), nicorhus (the abode of a hippopotamus).

В cр.-а. период наряду с многозначными словами, называющими и жилище животного, и другие реалии (nest 'the nest of an animal or insect', 'a home or dwelling place'; a place of rest; mansion 'the habitat of an animal'; home 'a shelter for hogs, a pen'; hǒus 'a structure for domestic animals and birds'), появились специальные слова, обозначавшие только жилища животных: stōd 'a place where horses or other animals are kept'; stāble 'a building for keeping horses'; pigges-hǒus 'a pigsty'; lair 'a place where an animal takes shelter'; kenel 'a dog house'; cote 'a shed, a pen'; caban 'a stall or coop for animals and birds' и др. [12].

Очевидно, появление специальной лексики для обозначения жилищ животных было связано с изменением структуры жилища человека: в то время как древнеанглийские фахверковые «длинные дома» объединяли под своей крышей и комнаты хозяина, и сараи для скота, в ср.-а. период здания для содержания животных стали строить отдельно рядом с жильем человека.

Последняя группа, не зафиксированная в составе ср.-а. интерпретационного поля жилище, объединяет слова с каким-либо весьма специфическим семантическим признаком, например, 'родительский дом', 'дом с огнем' или 'дом, который далеко отсюда': éðel-eard (a native dwelling), fceder-éðel (paternal home), feor-búend (a dwelling far off), fýr-hús (a room with a fire) [13]. Эти слова также исчезли из языка из-за своей узкой семантики и были замещены в основном словосочетаниями типа my faders hous.

В результате всех вышеописанных процессов в течение др.- и ср.-а. периодов произошли следующие изменения: количество групп, конституирующих интерпретационное поле концепта, осталось приблизительно таким же, однако состав их изменился: довольно большая часть лексики, репрезентирующей концепт жилище в др.-а. языке, в с.-а. периоде вышла из употребления, благодаря наплыву французских заимствований. В первую очередь отмирали сложные двухкомпонентные слова, как правило, производные и немногозначные. Они вытеснялись более простыми по структуре французскими словами, которые легко ассимилировались в английском. Кроме этого, выходили из употребления лексические единицы с большим объемом значения - широкозначные слова, такие как wic, не имевшие в своей семантике дифференциальных признаков, выделяющих их из группы конкурирующих слов. Они отмирали, становясь избыточными, либо развивали новые значения и переходили в группу с другим интегральным признаком (toun, éðel). Таким образом, группы изменились качественно при приблизительно одинаковом количественном наполнении.

\section{Анализ невербальных феноменов культуры др.-а и ср.-а. периодов}

Использование артефактов, относящихся к др.- и cp.-а. периодам, для лингвокультурологического анализа дополняет общую картину быта средневекового британца и позволяет категоризировать языковой материал, относящийся к концепту жилищее. 
B VII-IX вв. сельский дом строился из дерева. Клановые хутора преобразовались со временем в английские деревни, в центре которых стоял дом вождя - холл (heal), а вокруг - хижины сторонников и соратников. В таком холле, кроме жилых помещений, имелся бражный зал для собраний и праздников (a large room... in which the social, public life of the household is carried on), хлев для скотины ('a building for keeping animals'), отсеки для хранения зерна ('a building for storage, for the keeping of material'), как и в остальных домах. Прямо на полу разводили огонь (отсюда, вероятно, и слово fyr-hús). Традиционно такие конструкции называют «длинными домами».

Внутри поселения, обычно окруженного рвом с водой и частоколом, имелось особое место или здание для собраний и судов. Вероятно, этот факт повлиял на появление в семантике слова heall нового значения 'суд' (a building for legal business, a court of law). Обычно здесь же строили церковь или часовню, поэтому у hús, heall развились также значения 'церковь, храм'. В поэме «Беовульф» неоднократно упоминается о подобном «длинном доме» под названием Хеорот, где да́ны устраивали регулярные пиршества [22]. Таким образом, возникает широкозначное слово heall, обозначавшее и поселок, огороженный частоколом, и дом вождя, и бражный зал. Этот пример является иллюстрацией того, как устройство быта в деревне отражается в структуре лексического значения слова: в результате метонимического переноса heall развивает новые лексико-семантические варианты. Позднее распространилось строительство из камня, и в первую очередь появились каменные церкви. Некоторые из них сохранились, например, в Уилшире, Бредвелле в Эссексе, Бриксуорте в Нортгемптоншире, Брэдфорде-на-Эйвоне. Часто церкви были укомплектованы башнями, предназначение которых не вполне ясно. Существуют данные, что в этих башнях жили монахи [23]. Начиная с IX в. стали возводиться жилые дома с каменным первым этажом без оконных и дверных проемов, где хранили зерно, инструменты, оружие и т. п. Хозяева жили на верхних этажах, где располагался холл и личные комнаты. Такая структура жилища отразилась, вероятно, в семантике многозначных слов, например, hous номинировало и жилые комнаты, и помещения для хранения инвентаря (a room, apartment, or outbuilding specially devoted to domestic activity or household storage); stede - комнату, часть здания, занятого под какие-то другие цели (a chamber, room, cell, a space occupied by something; a portion or part of something) [13].

Поместья, которые существовали в Британии ранее, часто образовывали одно целое с замками, располагавшимися в центре имения. Структура такого жилья нашла отражение в словах tún, (a manor, an estate, etc.); ham (house with land, estate); wic (camp, castle, fortress); castel (castle, town, village). Замки феодалов с прилегающими домами вассалов становятся весьма распространенным типом сооружений в средние века. Начиная с IX в. и вплоть до эпохи Возрождения форма замков не менялась.

В среднеанглийский период меняется облик жилища и материал строений. В 1066 г. в результате нормандского завоевания Вильгельм стал королем Англии и развернул строительство феодальных замков по всей стране. Форты, как правило, строились на холмах или насыпях для хорошего обзора местности. Холм был обнесен оградой, внутри которой находились арсенал гарнизона, мастерские, зернохранилище, конюшни и стойла для скота и т. п. Часто за забором размещалась целая деревня с домами крестьян, ремесленников, там же располагались пекарня, мельница, колодец, иногда пруд, прилавки торговцев. За каменными стенами находился ров, по бокам выступающие башни, позволявшие защитникам стрелять из-за стен. Кроме внешнего двора мог быть и внутренний, с башней-донжоном в центре, которая одновременно служила и жилищем феодала. Примером подобного форта может служить Хедингем в Эссексе (XII в.) [24, с. 133]. Такая структура феодального замка отразилась, вероятно, в средствах номинации, когда одно многозначное слово, например castel, одновременно номинировало замок, крепость, военное укрепление, лагерь, небольшой город, деревню и т. д. [12; 25].

Кроме замков, существовало еще несколько разновидностей построек: в городах строились дома дворцового типа с внутренними дворами, где жили самые богатые и влиятельные люди.

Для простых людей (ремесленников, торговцев и пр.) строились более скромные и низкие жилища (до трех этажей). Посередине строения по высоте всего дома строили холл, вокруг которого размещались комнаты на каждом этаже. C XIV в. холл опустился на первый этаж, а на цокольном располагались производственные помещения или лавки, часто с кладовой и амбаром. Для строительства домов стали применять кирпич, иногда металл и стекло. Кровельным материалом выступали солома или более дорогая черепица. Описанные дома впервые были зарегистрированы в Саутгемптоне в конце XII - начале XIII вв. [26].

В деревнях, в пределах маноров, все еще остается большое количество фахверковых деревянных домов. Однако деревянные перекрытия на первом этаже постепенно стали заменяться каменными, что, вероятно, было вызвано потребностью разводить огонь внутри помещения. Представляется, что в климатических условиях Англии это было чрезвычайно важным условием для любого жилища. Структура 
деревенского дома практически не менялась: нормандское завоевание на ней не отразилось. Напротив, хижины крестьян и крепостных продолжали оставаться деревянными и примитивными [23, с. 180]. В XIII в. фахверковые хижины исчезают, будучи вытеснены усадебным домом фриголдера (bold, cynebold, burghbold, halle, logge, maner, stede). Вокруг центрального двора группировались бытовые и хозяйственные постройки (stede, hous), ядром же всего комплекса остается холл (halle). Сверху к нему примыкают жилые комнаты (bour, celle, chaumbre, flet, hous, roum, stede, ward), снизу - кладовые и кухня (если она существовала). Эта традиция долго удерживалась в Англии, особенно в сельской местности. На протяжении XIII в. растет количество каменных домов, однако холлы долго остаются деревянными. Только в XIV в. появляются холлы из камня, которые превращаются в парадные помещения с большими окнами и высокой крышей [23]. Лексемы, называющие такие сооружения, характеризуются наличием признака 'большой, роскошный': bour, halle, edifice, heighalle, hous, home, logge, mansion, palais, stede и др. В этот период жилища начинают украшать: стены обшивают дубом, пол выкладывают керамической плиткой. С распространением кирпичного производства в домах появляются камины, которые вытесняют центрально расположенные очаги. Главным украшением холла являлся эркер. В это время в семантической структуре многозначных слов зафиксированы значения 'дворец, особняк, величественное здание' и 'замок, башня, крепость' (bour, mansion, edifice, bold (cynebold) [12; 25]. Несколько крупных холлов XIV в. сохранились до нашего времени. Типичным примером могут служить усадебные дома Лоуэр Брэкхемптон и Пенсхёрст Плейс в графстве Кент [23]. Таким образом, словарный состав ср.-а. языка также не оставался неизменным, что опосредованно отразилось на структуре исследуемого концепта. Языковые средства довольно точно коррелируют со структурой средневекового жилья, развивая новые лексико-семантические варианты на основе сходства и смежности и называя одним словом и целый дом, и его отдельные компоненты.

С другой стороны, зафиксированы номинации для обозначения каждого типа и отдельного компонента жилища в означенный период, а также его характеристик и жильцов. Эти языковые единицы зачастую оказываются производными от полисемантов простой морфологической структуры, например: hous chaumbre (a storage room or work room), douves hus (a dove cote), swin hus, oxe hus, cou hus, etc.; hous cop (a house roof), hous dore (a house door); hous lord, hous ladi, hous meine, (servants), hous carpenter; hombakere (one who bakes bread at his home and sells it in the market), hompipe (a pipe supplying water to a house); dwellinge stede (a place of residence, a quarter or section of a city; a dwelling house with an attached piece of land) и др. [12]. Такие слова и словосочетания дополняют и уточняют структуру интерпретационного поля концепта жилище, а также отражают представления концептоносителя о жилище и способах концептуализации данного отрезка действительности.

\section{Заключение}

Представления о жилище эволюционировали в процессе развития средневекового общества, что нашло отражение как в языковых репрезентациях концепта жилище, так и в артефактах, связанных с ним. Неизменным осталось основное назначение жилья: защита от внешних сил и сурового климата.

В др.-а. период жилища были преимущественно деревянные, также были широко распространены одноэтажные «длинные дома» (с прилегающей к ним территорией), которые вмещали в себя холл для собраний и развлечений с комнатами для ночлега хозяев и гостей. Рядом с домом располагались церковь, холм для судов и собраний, отдельная кухня и сараи для скота. Начиная с XI в. образ жилища меняется, основной его функцией становится защита от врагов. Этот факт повлиял как на выбор материала для строительства, так и на структуру жилища: дома в городах все чаще становятся каменным.

Дома строятся двух- или трехэтажные, они вмещают как жилые комнаты на верхних этажах, куда было бы труднее добраться в случае нападения извне, так и хозяйственные помещения, магазины, мастерские на нижних. Городская знать обычно предпочитала дома дворцового типа. Такие дворцы имели внутренние дворы и могли примыкать к замкам, образуя единый укрепленный комплекс. Замки были ограждены каменными стенами и рвом с водой.

В деревнях же была распространена манориальная система, включавшая в себя дом лорда, фриголдеров и вилланов, жилища которых по-прежнему строили из дерева. Манор также мог включать в себя земельные наделы, здание суда, церковь или храм. На протяжении ср.-а. периода жилище фриголдеров эволюционировало от деревянного одноэтажного, где располагались как помещения для людей, так и хлевы для скота, до каменного двухэтажного с керамическим полом и эркерами. Неизменным элементом жилища на всем протяжении исследуемого периода оставался холл, который также менялся от деревянного помещения с очагом в центре до парадного помещения с высокой кровлей и большими окнами. Дома вилланов не изменились, они оставались деревянными хижинами на протяжении всей эпохи.

Изменения в архитектуре средневекового жилища нашли отражение в языке: др.-а. широкозначные слова совмещали в своей семантике большое коли- 
чество смыслов, но не имели содержательного стержня. Они номинировали одновременно жилище человека и животного, короля (вождя) и вилланов, воинов, мужчин и женщин, заключенных и т. д., т. е. эти слова обозначали жилище в общем смысле. Поэтому ядро др.-а. концепта жилище представлено семью широкозначными словами epel, ham, hus, heal, wic, tun, flet, семантика которых покрывает практически все интерпретационное поле. В ср.-а. языке состав ядра сокращается до трех слов с когнитивными признаками 'здание / структура для проживания человека/животного’, при этом hous и hom сохраняют свою позицию в языке, будучи многозначными, продуктивными, простой морфемной структуру, и поэтому жизнеспособными; французское заимствование dwellinge вытеснило иные синонимичные слова широкого значения, которые стали избыточными.

Интерпретационное поле ср.-а. концепта жилище меняется качественно: в составе групп появляется много французских заимствований, укоренившихся в английском языке и вытеснивших часть исконных английских слов. Например, группа с интегральным признаком 'жилище для животных' изменилась и качественно, и количественно, пополнившись лексемами французского происхождения, которые ассимилировались в английском и часто использовались в качестве компонентов сложных слов (например, swincote).

Репрезентанты концепта жилище находятся в тесных взаимоотношениях друг с другом: сходство исходных значений конкурирующих слов дает толчок к появлению в их семантической структуре сходных значений в последующие периоды. Появление нового слова или значения влечет за собой исчезновение старого или вытеснение одного из его значений для обеспечения эффективного покрытия семантического пространства в каждую конкретную эпоху.

Диахронический анализ семантической структуры лексики, репрезентирующей др.- и ср.-а. концепт жилище показал, что в большинстве случаев слово сохраняет первичные ядерные значения, в то время как производные периферийные смыслы выходят из употребления, и на их месте возникают другие, необходимые для обозначения нового артефакта или явления.

Таким образом, диахроническое исследование интерпретационного поля др.-а. и ср.-а. концепта жилище и его языковых манифестаций в совокупности с изучением объектов материальной культуры представляется наиболее плодотворным. Такой подход позволил получить более полные и объективные данные о структуре концепта, его эволюции и о процессах категоризации представлений о жилище в др.-а. и ср.-а. периоды.

\section{ЛИТЕРАТУРА}

1. Дорохова Н. И. Лингвосемиотика повседневной жизни англо-саксов в пространстве жилого хабитата // Вестник Волгогр. гос. ун-та. Сер. 2: Языкознание. 2012. № 2 (16). С. 129-134.

2. Желонкина Т. П. Языковая репрезентация концепта «жилище» как национальная особенность англоговорящего социума // Вестник РГУ им. И Канта. Сер.: Филологические науки. 2007. Вып. 2. С. 76-85.

3. Никулина Н. В. Формирование и функционирование категории английских наименований жилища (номинативно-семиотический анализ) : автореф. дис. ... канд. филол. наук. М., 2009. 24 с.

4. Винокурова М. В. Мир английского манора (на материалах земельных описей графств Ланкашир и Уилтшир второй половины XVI - первой трети XVII вв.). М. : Наука, 2004. 493 с.

5. Косминский E. А. Исследования по аграрной истории Англии ХІІІ в. М. ; Л. : Изд-во АН СССР, 1947. $484 \mathrm{c}$.

6. Сказкин С. Д. Очерки по истории западно-европейского крестьянства в Средние века. М. : Изд-во Моск. ун-та, 1968. $378 \mathrm{c}$.

7. Козырева О. А. Когнитивные аспекты исследования лингвокультурологического поля (на материале поля «дом/жилье») : автореф. дис. ... канд. филол. наук. М., 2003. 24 c.

8. Донскова И. И. Проблемы системного сопоставления разноязычной лексики (на прим. англ. и рус. лексики семант. поля «жилые здания и помещения») : автореф. дис. ... канд. филол. наук. М., 2001. 19 с.

9. Дуксова Н. А. Сопоставительный системный анализ лексики семантического поля «дом/жилье» на материале английского и русского языков : автореф. дис. ... канд. филол. наук. М., 2006. 26 с.

10. Клишин А. И. Структурно-семантический анализ тематических групп, обозначающих жилые объекты в современном русском и английском языках (гиперонимо-гипон. отношения) : дис. ... канд. филол. наук. Л., $1986.180 \mathrm{c}$.

11. Финкельштейн М. А. Лексико-семантическая группа синонимов «жилая комната» : на материале английского и немецкого языков : автореф. дис. ... канд. филол. наук. М., 2001. 18 с.

12. The Middle English Compendium of the University of Michigan. URL: https:/quod.lib.umich.edu/m/middleenglish-dictionary/

13. Bosworth J., Toller T. N. An Anglo-Saxon Dictionary : Based on the Manuscript Collections of the Late Joseph Bosworth. London : Clarendon Press, 1882. 1302 p.

14. Степанов Ю. С. Константы : словарь русской культуры. 3-е изд. М. : Академический проект, 2004. 990 c.

15. Лихачев Д. С. Концептосфера русского языка / Изв. РАН - СЛЯ. 1993. № 1. С. 3-9.

16. Попова 3. Д., Стернин И. А. Когнитивная лингвистика. М. : АСТ: Восток - Запад, 2007. 314 с. 
17. Никитин М. В. Основы когнитивной лингвистики. СПб., 2003. 277 с.

18. Стернин И. А. Методика исследования структуры концепта // Методологические проблемы когнитивной лингвистики / под ред. И. А. Стернина. Воронеж, 2001. C. 58-65.

19. Растворова Ю. С. Анализ языковых средств и форм материальной культуры в исследованиях концепта жилище в среднеанглийский период : городские жилища. Замковый комплекс // Вестник Южно-Уральского гос. ун-та. 2016. Т. 13, № 2. С. 9-15.

20. Семашко Л. А. Лексико-семантическая группа древнеанглийских существительных со значением «дом, жилище» : автореф. дис. ... канд. филол. наук. Ленинград, $1987.15 \mathrm{c}$.

21. Растворова Ю. С. Анализ языковых средств и форм материальной культуры в исследованиях концепта жилище в древнеанглийский период // Вестник ЛГУ. 2015. T. 1, № 2. С. 233-244.

22. Беовульф. Старшая Эдда. Песнь о Нибелунгах. (Библиотека всемирной литературы. Серия первая. Т. 9) М. : Худож. лит-ра, 1975. 770 с.

23. Всеобщая история архитектуры, Архитектура Западной Европы. Средние века / под ред. А. А. Губера (отв. ред.) [и др.]. Ленинград ; Москва, 1966. Т. 4. 694 с.

24. Квеннел М., Квеннел Ч. Г. Б. Повседневная жизнь в Англии во времена англосаксов, викингов и норманнов. СПб., 2002. 420 c.

25. Mayhew A. L., Skeat W. W. A concise dictionary of Middle English from AD 1150 to AD 1580. Oxford : The Clarendon Press, 1888. 303 p.

26. Platt $C$. Medieval England : A social history and archeology from the Conquest to 1600 AD. London : Routledge, 1978. 182 p.

\section{REFERENCES}

1. Dorokhova N. I. Lingvosemiotika povsednevnoy zhizni anglo-saksov v prostranstve zhilogo khabitata [Linguo-semiotics of Anglo-Saxon routine life within the space of living habitat] // Vestn. Volgogr. gos. un-ta. Seriya 2: Yazykoznaniye. 2012. № 2 (16). Pp. 129-134.

2. Zhelonkina T. P. Yazykovaya reprezentatsiya kontsepta zhilische kak natsionalnaya osobennost anglogovoryashchego sotsiuma [Linguistic manifestations of the concept HABITATION as a national feature of the English society]. In Vestnik RGU im. I Kanta. Seriya: Filologicheskiye nauki. 2007. Vyp. 2. Pp. 76-85.

3. Nikulina N. V. Formirovaniye i funktsionirovaniye kategorii angliyskikh naimenovaniy zhilishcha (nominativno-semioticheskiy analiz) [The formation and functioning of the category of words naming dwellings in English]: avtoref. Dis. ... kand. filol. nauk. M., 2009. 24 p.

4. Vinokurova. M. V. Mir angliyskogo manora (na materialakh zemelnykh opisey grafstv Lankashir i Uiltshir vtoroy poloviny XVI-pervoy treti XVII vv.) [The world of the English manor (based on the Hudred Rolls in Lancashire and Wiltshire in the $16^{\text {th }}$ and $\left.17^{\text {th }} \mathrm{cc}.\right)$ ]. M.: Nauka, 2004. $493 \mathrm{p}$.
5. Kosminskiy E. A. Issledovaniya po agrarnoy istorii Anglii XIII $v$. [Research on agrarian history of England of the $13^{\text {th }}$ c.]. M.; L.: Izd-vo AN SSSR, 1947. 484 p.

6. Skazkin S. D. Ocherki po istorii zapadno-evropeyskogo krestianstva $v$ Sredniye veka [Essays on the history of the West European peasantry in the Middle Ages]. M.: Izdatelstvo Moskovskogo Universiteta, 1968. 378 p.

7. Kozyreva O. A. Kognitivnyye aspekty issledovaniya lingvokulturologicheskogo polya (na materiale polya «dom/ zhilye») [A cognitive study of linguistic and cultural aspects of meaning in field semantics: The case of the lexical field of words denoting a living space]: Avtoref. dis. ... kand. filol. nauk. M., 2003. 24 p.

8. Donskova I. I. Problemy sistemnogo sopostavleniya raznoyazychnoy leksiki (Na prim. angl. i rus. leksiki semant. polya "zhilyye zdaniya i pomeshcheniya") [The problems of systematic correlation of word meanings in different languages: The case of English and Russian words denoting living space]: Avtoref. dis. ... kand. filol. nauk. M., 2001. $19 \mathrm{p}$.

9. Duksova N. A. Sopostavitelnyy sistemnyy analiz leksiki semanticheskogo polya "dom/zhilye" na materiale angliyskogo i russkogo yazykov [A comparative analysis of words denoting living space in English and Russian]: Avtoref. dis. ... kand. filol. nauk. M., 2006. 26 p.

10. Klishin A. I. Strukturno-semanticheskiy analiz tematicheskikh grupp, oboznachayushchikh zhilyye obyekty $v$ sovremennom russkom i angliyskom yazykakh (giperonimo-gipon. otnosheniya) [A structural and semantic analysis of word-groups denoting dwellings in Modern Russian and English: Their hyper-hyponymic relations]: Dis. kand. filol. nauk. L., 1986. 180 p.

11. Finkelshteyn M. A. Leksiko-semanticheskaya gruppa sinonimov "zhilaya komnata": Na materiale angliyskogo i nemetskogo yazykov [The lexcial and semantic group of words denoting a living room in the English and German languages]: Avtoreferat dis. ... kand. filol. nauk. M., 2001. $18 \mathrm{p}$.

12. The Middle English Compendium of the University of Michigan. Available at: https://quod.lib.umich.edu/m/ middle-english-dictionary/

13. Bosworth J., Toller T. N. An Anglo-Saxon Dictionary: Based on the Manuscript Collections of the Late Joseph Bosworth. London: Clarendon Press, 1882. 1302 p.

14. Stepanov Yu. S. Konstanty: Slovar russkoy kultury [Constants: A Dictionary of Russian Culture]. Izd. 3-e. ispr. i dop. M.: Akademicheskiy Proyekt, 2004. 991 p.

15. Likhachev D. S. Kontseptosfera russkogo yazyka [The Conceptual Sphere of the Russian Language]. Izvestiya RAN. Ser. lit. i yaz. M., 1993. T. 52. № 1. Pp. 3-9.

16. Popova. Z. D., Sternin. I. A. Kognitivnaya lingvistika. [Cognitive Linguistics]. M.: ACT: Vostok-Zapad, 2010. $314 \mathrm{p}$.

17. Nikitin M. V. Osnovy kognitivnoj lingvistiki [Basics of Cognitive Libguistics]. Sankt-Peterburg: Izd-vo RGPU, 2003. $277 \mathrm{p}$.

18. Sternin I. A. Metodika issledovaniya struktury kontsepta [Concept Structure and its Methodology]. Metodologicheskiye problemy kognitivnoy lingvistiki: Nauch- 
noye izdaniye / Pod redaktsiyey I. A. Sternina. Voronezh, 2001. Pp. 58-65.

19. Rastvorova Y. S. Analiz yazykovykh sredstv i form materialnoy kultury $v$ issledovaniyakh kontsepta zhilische v sredneangliyskiy period: gorodskiye zhilishcha. Zamkovyy kompleks [The Middle English Concept dwelling and its Manifestations through Language Means and Artifacts: City Dwellings, Castle Complexes] // Vestnik Yuzhno-Uralskogo gos. un-ta, 2016. T. 13. № 2. Pp. 9-15.

20. Semashko L. A. Leksikosemanticheskaya gruppa drevneanglijskikh sushhestvitel'nykh so znacheniem DOM, ZHILISCHE [The Lexico-Semantic Group of Old English Nouns Meaning HOUSE, DWELLING]: avtoref. dis. kand. filol. nauk. L. A. Semashko. Leningrad, 1987. 15 p.

21. Rastvorova Y. S. Analiz yazykovykh sredstv i form material'noj kul 'tury v issledovaniyakh kontsepta ZHILISH$H E v$ drevneanglijskij period [The Old English Concept DWELLING and its Manifestations through Language Means and Artifacts]. Vestn. LGU, 2015. Tom 1. № 2. P. 233-244.

Высшая икола экономики

Растворова Ю. С., кандидат филологических наук, стариий преподаватель департамента иностранных языков

E-mail: jul31057@mail.ru

Пушкарев Е. А., кандидат филологических наук, старший преподаватель департамента иностранных языков

E-mail: auldington@gmail.com

Поступила в редакциию 12 сентября 2019 г.

Принята к публикации 25 марта 2020 г.

\section{Для цитирования:}

Растворова Ю. С., Пушкарев Е. А. Эволюция представлений о жилище и его номинаций в древне- и среднеанглийский период // Вестник Воронежского государственного университета. Серия: Лингвистика и межкультурная коммуникация. 2020. № 2. С. 65-74. DOI: https://doi.org/10.17308/lic.2020.2/2842
22. Beovulf. Starshaya Edda. Pesn' o Nibelungakh [Beowulf. Poetic Edda. The Nibelungenlied]. (Biblioteka vsemirnoy literatury. Seriya pervaya. T. 9). M.: Khudozhestvennaya literatura. $1975.770 \mathrm{p}$.

23. Vseobshchaya istoriya arkhitektury. Arkhitektura Zapadnoy Evropy. Sredniye veka [The General History of Architecture. West European Architecture in the Middle Ages]. Pod red. A. A. Gubera (otv. red.), N. D. Kolli., P. N. Maksimova, I. L. Matsa i dr. L.; M.: Stroyizdat, 1966. T. 4.694 p. il.

24. Kvennell M. Kvennel Ch. G. B. Povsednevnaya zhizn $v$ Anglii vo vremena anglosaksov, vikingov i normannov [The Everyday Life in Anglo-Saxon, Viking, and Norman Times]. Per. s angl. Kovaleva T. V. SPb.: Evraziya, 2002. 384 p.

25. Mayhew A. L., Skeat W. W. A concise dictionary of Middle English from AD 1150 to AD 1580. Oxford: The Clarendon Press, 1888. 303 p.

26. Platt C. Medieval England: a social history and archeology from the Conquest to 1600 AD. London: Routledge, 1978. $182 \mathrm{p}$.

Higher School of Economics

Rastvorova Yu. S., Candidate of Philology, Senior Lecturer of Foreign Languages Department

E-mail: jul31057@mail.ru

Pushkarev E. A., Candidate of Philology, Senior Lecturer of Foreign Languages Department

E-mail: auldington@gmail.com

Received: 12 September 2019

Accepted: 25 March 2020

\section{For citation:}

Rastvorova Yu. S., Pushkarev E. A. The Evolution of the concept of a living space and its nominations in the old and middle english periods. Proceedings of Voronezh State University. Series: Linguistics and Intercultural Communication. 2020. No. 2. Pp. 65-74. DOI: https://doi. org/10.17308/lic.2020.2/2842 